\title{
Internet based social networks as the resource supporting International
}

\section{new venture creation}

\author{
Piotr Tomski ${ }^{\mathrm{a}^{*}}$, Felicjan Bylok ${ }^{a}$, Dorota Jelonek $^{a}$, Elzbieta Wyslocka $^{a}$ \\ ${ }^{\text {a }}$ Czestochowa University of Technology, Poland \\ *Corresponding author: Piotr Tomski, Ph.D., Assoc. Prof., tomskip@wp.pl
}

\begin{abstract}
The internationalization process is important both for new ventures and established enterprises. The information obtained from international contacts of the entrepreneur (using internet based social networks) may be useful and may support the internationalization process. The aim this study is to analyze undergraduates' entrepreneurial intentions focused on international business activity on the example of students of Faculty of Management of Czestochowa University of Technology (Poland).
\end{abstract}

Key words: entrepreneurship, internationalization, social networks, Internet, SNS

\section{Introduction}

The fact that, nowadays, a lot of small and medium enterprises do not undergo internationalization in a classic way, in accordance with the sequential Uppsala model, but the process of internationalization is accelerated, deserves a special attention. Facing the fact that the process of internationalization has been accelerating, the specificity of intentions, concerning internationalization of the company, occurring at the stage of intentions, referring to the beginning of business activity, seems to be interesting.

The essence and sources of internationalization are really complex since they are shaped by many closely related and considerably interdependent factors. An important feature of this process is its multidimensionality, consisting in interlinking the economic and social spheres, which is manifested in the significant role of the entrepreneur, whereas, at the stage of intentions - the nascent entrepreneur.

Internationalization may be referred to as building relationship with partners or foreign markets $^{1}$. All the listed activities must be, however, supported by access to and use of appropriate information. As Hart, Webb and Marian ${ }^{2}$ underline, the ability of the firm to 
utilize the international information is vital to the success of plans referring to export activities. In this context, it is worth paying attention to the Internet and social media.

As Petersen, Welch and Liesch ${ }^{3}$ underline, the mainstream theory on firm internationalization considers information and knowledge to be critical resources for the international expansion of the firm. Knowledge is acquired through standardized methods of collection and transmission of information. Clearly, the Internet has a vast potential for facilitating firms' acquisition of objective knowledge.

As the Internet has revolutionized the way individuals access and gain information, also the information on the possibilities of internationalization is available via this kind of communication. The information derived from social networking sites (SNS) from international contacts of the entrepreneur may be useful and may support the internationalization process.

The aspect additionally emphasizing the necessity of arousing interest in the role of social network and the Internet as the factors stimulating entrepreneurial intentions directed towards internationalization of the company is the fact that firms use their collaborative networks to gain access to resources, to improve their strategic positions, to control transaction costs, to learn new skills, to gain legitimacy, and to cope positively with rapid technological change. ${ }^{4}$ The reference to the resources available in the social network of the entrepreneur may influence intentions of the entrepreneur directed towards internationalization of the future company.

In the light of the above, the objective of the study is to examine undergraduates' entrepreneurial intentions concerning international activity on the example of students of Faculty of Management of Czestochowa University of Technology (FoMCUT) in Poland.

\section{The Internet and social media - source of information supporting internationalization}

The emergence of internationalized firms has been strongly influenced by trends towards the globalization of business activity and the impact of new process and communication technologies, ${ }^{5}$ key among these being the Internet. ${ }^{6}$ The Internet has been proposed to enhance firms' capacities to obtain international information ${ }^{7}$ and transfer knowledge ${ }^{3}$ in the process of internationalization. Mathews and Healy ${ }^{8}$ found evidence suggesting that Internet implementation within firms enhanced the information and knowledge capabilities of internationalizing small and medium firms, which in turn had a positive impact on the path and pace of that firm's internationalization. 
The Internet enhances the information components of internationalization ${ }^{8}$ and the Internet assists in generating foreign-market expansion for the firm. ${ }^{9}$ It has also been suggested that the Internet has a positive effect on the firm's ability to internationalize rapidly. ${ }^{10}$ It has been suggested that the Internet will enhance the firm's ability to access information, as well as disseminate information to potential international customers. ${ }^{7}$

As Hamill and Gregory ${ }^{7}$ observe, an Internet connection can 'substantially improve communications with existing foreign customers, suppliers, agents and distributors, identify new customers and distributors, and generate a wealth of information on market trends and on the latest technology and research and technical developments'. It also provides a more effective way of developing and maintaining relationships with customers, channel partners, suppliers, and network partners. ${ }^{11}$ Networking constitutes a chance to interact with people, build friendships or business partnerships, identify opportunities, and create value. Technology has supported this process to be easier, since individuals can readily contact others who were previously unknown. ${ }^{12}$

Kaplan and Haenlein ${ }^{13}$ define social media as "a group of Internet-based applications [...] that allow the creation and exchange of user-generated content”. Such applications constitute SNSs. Boyd and Ellison ${ }^{14}$ define them as: web-based services that allow individuals to construct a public or semi-public profile within a bounded system, articulate a list of other users with whom they share a connection, and view and traverse their list of connections and those made by others within the system. SNSs are the most popular and fastest growing types of Internet sites. ${ }^{15}$ The rise of social media and online communities enable individuals to easily share and access information. ${ }^{16}$

Internet social media undoubtedly support the creation and maintenance of social networks and personal relations. Social networks and personal relations inevitably play an important part in structuring economic activities. They may facilitate access to a variety of useful resources for entrepreneurs, such as information, ideas and knowledge (about markets, activities, and skills) or financial and material support. ${ }^{17}$

\section{The research model and hypotheses}

The entrepreneur is of crucial importance for creating the future company and entrepreneurial intentions are the basis for providing the form of future economic ventures, the entrepreneur (and their background) is, most of all, the one to constitute the basis for creating the specificity of developing a new company. Great importance of information on foreign markets, for the process of internationalization, indicates that the more information on 
internationalization and specificity of target markets is possessed by the entrepreneur, the more probable it is that they will have the intention to aim at internationalization of their new company. In the contemporary world, particularly for young people that students are, the key source of information is the Internet. Acquaintances made and maintained via social media may constitute the source of valuable and unique resources which may support internationalization both in material and non-material sense. According to that, four hypotheses are proposed: H1: The number of foreigners belonging to "contacts" in the nascent entrepreneur's profile on SNS positively affects the level of firm internationalization; H2: The number of Poles living abroad belonging to "contacts" in the nascent entrepreneur's profile on SNS positively affects the level of firm internationalization; H3: The number of people frequently travelling abroad belonging to "contacts" in the nascent entrepreneur's profile on SNS positively affects the level of firm internationalization; H4: There is a common positive influence of the number of foreigners, Poles living abroad or people frequently travelling abroad belonging to „contacts” in the nascent entrepreneur's profile on social networking sites on the level of firm internationalization.

\section{Research method, sample and variable measurement}

The research was conducted among the group of 441 students of the FoMCUT. Only 31.97\% declared their intentions concerning setting up their own company within the nearest 5 years. Therefore, the results of the present study refer to 141 students declaring that, within the nearest 5 years, they would set up their own business. The research was carried out using CAWI method.

The relationship between the variables was specified by estimation of monotonic Spearman correlation and Pearson linear correlation coefficients. Additionally, there were estimated the simple and multiple linear regression models and the model of regression with interactions.

The measurement tool for the assessment of the level of firm internationalization is based on two seminal concepts of incremental internationalization. The first model constituting the basis for the measurement tool is the Bilkey and Tesar $^{18}$ idea of incremental internationalization of "smaller-sized" firms. The other one is the Uppsala model. ${ }^{19}$ Hence, the level of the internationalization (INT) is operationalized by the following statement: "The involvement of my future firm on foreign markets can be defined as follows:". The answers reflect the stages of firm internationalization. The first statement (1) reflects the lowest level of internationalization and the last one (10) refers to the highest level of internationalization. 
The measurement of social media impact is based on the understanding of the main foreign actors being the nascent entrepreneur's contacts in social media profile which are foreign friends, Poles living abroad and Poles frequently travelling abroad. Those contacts are selected as the most influential ones with respect to the provision of "foreign" information for the entrepreneur. The selection is based on previous qualitative studies and the research on a group of small enterprises. ${ }^{20}$ This measurement is based on three scales. Therefore, those variables are operationalized by three statements, the answers to which were given on three 10-item scales. SNS Foreign Contacts of Students (FC) is operationalized by the number of foreigners belonging to "contacts" in student's profile on SNS. SNS Emigrant Contacts of Students (EC) is operationalized by the number of Poles living abroad, belonging to your “contacts” in student's profile on SNS. SNS Frequent Traveller Contacts of Students (FTC) is operationalized by the number of people frequently travelling abroad, belonging to "contacts" in student's profile on SNS.

\section{Results of the research}

The assessment of the relationship between variables occurring in the research model was the second stage of the research. The coefficients are shown in Table 1.

Table 1. The relationship between the variables - correlation coefficients

\begin{tabular}{|l|l|l|l|l|}
\hline \multirow{2}{*}{} & \multicolumn{2}{|c|}{ Monotonic Spearman correlation } & \multicolumn{2}{c|}{ Pearson linear correlation } \\
\cline { 2 - 5 } & $\mathrm{r}$ & $\mathrm{p}$ & $\mathrm{r}$ & $\mathrm{p}$ \\
\hline FC & 0.7499 & $<0.0001$ & 0.7392 & $<0.0001$ \\
\hline EC & 0.7385 & $<0.0001$ & 0.7456 & $<0.0001$ \\
\hline FTC & 0.8880 & $<0.0001$ & 0.8723 & $<0.0001$ \\
\hline
\end{tabular}

There were also identified highly significant $(\mathrm{p}<0.0001)$ positive correlations at a high level between INT and FC, EC and FTC. This proves that the number of foreigners belonging to "contacts" in the profile on SNS, the number of Poles living abroad, belonging to "contacts" in the profile on SNS and the number of people frequently travelling abroad are strictly connected with the level of internationalization of the future company, that is, the more such acquaintances the higher internationalization level of such a hypothetical company. After assessing correlation coefficients, there were estimated the models of simple linear regression, multiple linear regression and regression with interactions (Tab. 2, 3, 4). 
Table 2. The relationship between the variables - simple linear regression

\begin{tabular}{|r|r|r|r|r|r|r|r|r|}
\hline & b coeff. & b error & $-95 \%$ CI & $+95 \%$ CI & t stat & p-value & b stand. & $\begin{array}{c}\text { b stand. } \\
\text { error }\end{array}$ \\
\hline intercept & 1.85 & 0.25 & 1.36 & 2.34 & 7.50 & $<0.0001$ & & \\
\hline FC & 0.82 & 0.06 & 0.69 & 0.94 & 12.99 & $<0.0001$ & 0.74 & 0.06 \\
\hline intercept & 1.58 & 0.26 & 1.07 & 2.09 & 6.09 & $<0.0001$ & & \\
\hline EC & 0.83 & 0.06 & 0.71 & 0.96 & 13.24 & $<0.0001$ & 0.75 & 0.06 \\
\hline \multicolumn{8}{|c|}{$\mathrm{R}=0.7456, \mathrm{R}^{\wedge} 2=0.5559, \mathrm{R}^{\wedge} 2$ adjusted $=0.5528$, standard error of estimate $=1.66$} \\
\hline intercept \\
\hline FTC
\end{tabular}

There were identified highly significant $(\mathrm{p}<0.0001)$ positive correlations at a high level between INT and FC, EC and FTC. This proves that the number of foreigners belonging to "contacts" in the profile on SNS, the number of Poles living abroad, belonging to "contacts" in the profile on SNS and the number of people frequently travelling abroad are strictly connected with the level of internationalization of the future company, that is, the more the acquaintances of this type the higher the planned level of its internationalization (on the basis of intentions).

Table 3. The relationship between the variables - multiple regression

\begin{tabular}{|r|r|r|r|r|r|r|r|r|}
\hline & b coeff. & b error & $-95 \%$ CI & \multicolumn{1}{|c|}{$+95 \%$ CI } & t stat & p-value & b stand. & $\begin{array}{c}\text { b stand. } \\
\text { error }\end{array}$ \\
\hline intercept & 0.70 & 0.20 & 0.29 & 1.10 & 3.41 & 0.0008 & & \\
\hline FC & 0.20 & 0.09 & 0.02 & 0.38 & 2.18 & 0.0312 & 0.18 & 0.08 \\
\hline EC & -0.08 & 0.10 & -0.29 & 0.12 & -0.81 & 0.4176 & -0.08 & 0.09 \\
\hline FTC & 0.79 & 0.08 & 0.64 & 0.95 & 10.30 & $<0.0001$ & 0.79 & 0.08 \\
\hline \multicolumn{7}{|c|}{$\mathrm{R}=0.8772, \mathrm{R}^{\wedge} 2=0.7694, \mathrm{R}^{\wedge} 2$ adjusted $=0.7644$, standard error of estimate $=1.20$} \\
\hline
\end{tabular}

In case of multiple regression the impact of EC was found not to be significant, whereas the impact of FC is significant and the impact of FTC on INT is highly significant.

Table 4. The relationship between the variables - multiple regression with interaction

\begin{tabular}{|c|c|c|c|c|c|c|c|c|}
\hline & b coeff. & b error & $-95 \%$ CI & $+95 \%$ CI & t stat & p-value & b stand. & $\begin{array}{c}\text { b stand. } \\
\text { error }\end{array}$ \\
\hline intercept & 0.64 & 0.44 & -0.24 & 1.52 & 1.44 & 0.1507 & 0.58 & 0.40 \\
\hline FC & -0.49 & 0.38 & -1.24 & 0.26 & -1.28 & 0.2028 & -0.44 & 0.34 \\
\hline EC & 0.93 & 0.18 & 0.58 & 1.28 & 5.30 & $<0.0001$ & 0.93 & 0.18 \\
\hline FTC & -0.73 & 0.39 & -1.52 & 0.05 & -1.86 & 0.0676 & -0.60 & 0.32 \\
\hline FC*EC & 0.01 & 0.09 & -0.17 & 0.20 & 0.16 & 0.8694 & 0.11 & 0.68 \\
\hline FC*FTC & -0.10 & 0.07 & -0.24 & 0.04 & -1.40 & 0.1647 & -0.78 & 0.56 \\
\hline EC*FTC & 0.04 & 0.05 & -0.07 & 0.15 & 0.72 & 0.4707 & 0.32 & 0.44 \\
\hline FC*EC*FTC & 0.00 & 0.01 & -0.02 & 0.03 & 0.27 & 0.7858 & 0.19 & 0.70 \\
\hline \multicolumn{7}{|c|}{$\mathrm{R}=0.8799, \mathrm{R}^{\wedge} 2=0.7742, \mathrm{R}^{\wedge} 2$ adjusted $=0.7624$, standard error of estimate $=1.21$} \\
\hline
\end{tabular}

In case of multiple regression with interactions, the impact of EC and FTC was found not to be significant, whereas the impact of FC on INT is highly significant. Interactions between predictors are not significant, either. 


\section{Conclusions}

In these conditions, again, it is worth underlining the fact that each entrepreneur and basically a nascent entrepreneur plays the key role in creating a new company. The image of this company, created at the stage of developing entrepreneurial intentions amounts to the form of a new company and its functioning on the local or global market. At the stage of intentions, there is also created the level of internationalization of the company since the primary vision created by the future entrepreneur is the pattern for directions of development of the company. Summing up the results of the conducted quantitative research, it can be concluded that there is significant impact of possessing a group of friends in the profile on social networking sites who constitute the source of information concerning foreign affairs. Both the number of foreigners, the number of Poles living abroad and the number of people frequently travelling abroad, belonging to “contacts” in the nascent entrepreneur's (student) profile on SNSs positively affect the level of internationalization of the analyzed companies. The joint positive impact refers to the interaction of foreigners and people frequently travelling abroad, the interaction of Poles living abroad and people frequently travelling abroad and the interaction of foreigners from among Poles living abroad and people frequently travelling abroad. However, the interactions are not statistically important. According to the results of the research H1, H2, H3 are supported but $\mathrm{H} 4$ hypothesis is not supported.

The students' intentions and attitudes towards internationalization of enterprises will definitely affect their future actions and decisions. The presence of the concept of internationalization at the stage of formulating plans of future activity or its lack will also have a critical impact on the fate of future enterprises set up by the respondents. It is necessary to underline that the key role of the person of a nascent entrepreneur is in the center of the project while affecting its competitiveness, used resources, possessed capabilities and the directions of development. As Johanson and Vahlne $e^{21}$ argue, the business environment as such has to be viewed as a web of relationships. According to Coviello ${ }^{22}$, insidership in networks, developed before entry in a new market, even before foundation of the firm, is seen as instrumental to the specific internationalization process.

\section{References}

1. B. Jankowska, Internacjonalizacja klastrów, Gospodarka Narodowa 5-6 (2010) 19-40.

2. S. Hart, J. Webb, J. Marian, Export marketing research and the effects of export experience in industrial SMEs, International Marketing Review 11(6) (1994) 4-22. 
3. B. Petersen, L.S. Welch, P.W. Liesch, The Internet and foreign market expansion by firms, Management International Review (2002) 207-221.

4. S.A. Alvarez, J.B. Barney, How entrepreneurial firms can benefit from alliances with large partners, Academy of Management Executive 15 (2001) 139-148.

5. G. Knight, S.T. Cavusgil, The born global firm: A challenge to traditional internationalization theory, Advances in International Marketing, 8 (1996) 11-26.

6. J. Bell, S. Loane, 'New-wave' global firms: Web 2.0 and SME internationalisation, Journal Of Marketing Management, 26(3/4) (2010) 213-229

7. J. Hamill, K. Gregory, Internet marketing in the internationalisation of UK SME's, Journal of Marketing Management 13(1-3) (1997) 9-28.

8. S. Mathews, M. Healy, From garage to global: The Internet and international market growth, an SME perspective, Int. J. Internet Mark. and Advert. 4(2/3) (2008) 179-196.

9. M. Kotabe, K. Helsen, Global marketing management, Hoboken, NJ: Wiley, 2004.

10. R. Wickramasekera, G. Bamberry, An overview of a successful export industry from regional Australia, Int. J. Wine Marketing 15(3) (2003) 15-30.

11. T. Coltman, T. Devinney, A. Latukefu, D. Midgely, E-business: Revolution, evolution, or hype? California Management Review 44 (2001) 57-86.

12. R.M. Peterson, H.F. Dover, Building Student Networks with LinkedIn: The Potential for Connections, Internships, and Jobs, Marketing Education Rev. 24(1) (2014) 15-20.

13. A.M. Kaplan, M. Haenlein, Users of the world, unite! The challenges and opportunities of social media, Business Horizons 53(1) (2010) 59-68.

14. D.M. Boyd, N.B. Ellison, Social network sites: Definition, history and scholarship, Journal of Computer Mediated Education, 13(1) (2007) 210-230.

15. S. Asur, B.A. Huberman, Predicting the future with social media. Web Intelligence and Intelligent Agent Technology, IEEE/WIC/ACM Int. Conference 1 (2010) 492-499.

16. J. Chen, H. Xu, A.B. Whinston, Moderated online communities and quality of usergenerated content. J. Management Information Systems, 28(2) (2011) 237-268.

17. J.P. Berrou, F. Combarnous, The Personal Networks of Entrepreneurs in an Informal African Urban Economy: Does the 'Strength of Ties' Matter?. Rev. Social Economy 70(1) (2012) 1-30.

18. W.J. Bilkey, G. Tesar, The export behavior of smaller-sized Wisconsin manufacturing firms. Journal of international business studies 9 (1977) 93-98. 
19. J. Johanson, F. Wiedersheim-Paul, The internationalization of the firm-four swedish cases 1, Journal of management studies 12(3) (1975) 305-323.

20. P. Tomski, Information Technology and Firm Internationalization, App. Mech. and Materials 795 (2015) 227.

21. J. Johanson, J-E. Vahlne, The Uppsala internationalization process model revisited: From liability of foreignness to liability of outsidership, J. Int. Bus. Stud 40(9) (2009) 1411-1431.

22. N.E. Coviello, The network dynamics of international new ventures, Journal of International Business Studies 37(5) (2006) 713-731. 